\title{
Identification of mimotopes of Mycobacterium leprae as potential diagnostic reagents
}

\author{
Silvana M Albann ${ }^{1}$, Juliana Ferreira de Moura², João Carlos Minozzo ${ }^{3}$, Marcelo Távora Mira ${ }^{4}$ \\ and Vanete Thomaz Soccol ${ }^{{ }^{*}}$
}

\begin{abstract}
Background: An early diagnostic test for detecting infection in leprosy is fundamental for reducing patients' sequelae. The currently used lepromin is not adequate for disease diagnosis and, so far, no antigen to be used in intradermoreaction has proved to be sensitive and specific for that purpose. Aiming at identifying new reagents to be used in skin tests, candidate antigens were investigated.

Methods: Random peptide phage display libraries were screened by using antibodies from leprosy patients in order to identify peptides as diagnostic reagents.

Results: Seven different phage clones were identified using purified antibodies pooled from sera of leprosy patients. When the clones were tested with serum samples by ELISA, three of them, 5A, 6A and 1B, allowed detecting a larger number of leprosy patients when compared to controls. The corresponding peptides expressed by selected phage clones were chemically synthesized. A pilot study was undertaken to assess the use of peptides in skin tests. The intradermal challenge with peptides in animals previously sensitized with Mycobacterium leprae induced a delayed-type hypersensitivity with peptide 5A (2/5) and peptide 1B (1/5). In positive controls, there was a $3 / 5$ reactivity for lepromin and a $4 / 5$ reactivity of the sensitized animals with soluble extract of $M$. leprae.
\end{abstract}

Conclusions: The preliminary data suggest that may be possible to develop reagents with diagnostic potential based on peptide mimotopes selected by phage display using polyclonal human antibodies.

\section{Background}

Leprosy is a chronic granulomatous infectious disease caused by $M$. leprae that affects the skin and the peripheral nervous system [1]. This disease constitutes a public health problem in countries such as Brazil [2], where large numbers of patients with sequelae as a result of neural damages are still observed every year [3]. Upon the introduction of multidrug therapy in 1981 by the WHO, the prevalence of leprosy has been dramatically reduced, but over the last 5 years, more than 200,000 new cases have been detected each year [4]. These more recent data indicate that the transmission of leprosy still goes on [5], which makes it clear that new strategies besides treatment - are necessary to eliminate the disease as a public health problem.

\footnotetext{
*Correspondence: vanetesoccol@gmail.com

'Engenharia de Bioprocessos e Biotecnologia, Universidade Federal do Paraná, Curitiba 81531-990, Brasil

Full list of author information is available at the end of the article
}

Leprosy presents a wide range of clinical manifestations determined by the immune response of the individual against the bacillus. Tuberculoid leprosy patients show a response that limits pathogen growth and result in few lesions containing rare (or absence of) bacilli however, nerve damage is often present. Lepromatous leprosy patients are susceptible to disseminated infection. Skin lesions are numerous and there is an uncontrolled proliferation of leprosy bacilli. Such clinical presentations correlate to the level of cell-mediated immunity (CMI) against $M$. leprae. Antibody responses are greater in lepromatous patients, indicating that humoral immunity does not contribute to host defense [6].

The delayed-type hypersensitivity reaction (DTH) in skin tests is considered a manifestation of the cell-mediated immunity [2]. In leprosy, cells of $M$. leprae from different origins and submitted to different processes of purification are the basis for different types of preparations employed in skin tests. Among those preparations, the most frequently used is lepromin, which corresponds to a 
suspension of heat-killed bacilli [7]. As M. leprae is not cultivated in vitro, cells for lepromin preparation can only be obtained from naturally infected human tissues (lepromas) or from experimentally infected armadillos [8].

Two types of positive skin reactions are described after the intradermal injection of $0.1 \mathrm{~mL}$ of lepromim: an early reaction (Fernandez Reaction), read after 48-72 hours; and a late reaction (Mitsuda Reaction), read after 3-4 weeks [9]. The Mitsuda reaction is measured as induration and provides a measure of the individual's ability to mount a granulomatous response against mycobacterial antigens [7]. Positive Mitsuda reactions are seen in the vast majority of contacts and unexposed individuals, as well as in tuberculoid leprosy patients; in leprosy patients with lepromatous disease no response is observed. Therefore, reactivity to lepromin can not used for diagnosis, but has a prognostic value [9]. In Brazil, the Centro de Produção e Pesquisa de Imunobiológicos (CPPI) is the only supplier of lepromin antigen for the Brazilian Department of Health, and its production is based on lepromas obtained from lepromatous leprosy patients. This is a difficult process because the production of the antigen depends on access to rare lepromas that may be contaminated with other species of mycobacteria [10]. In addition, the strategy is associated with the risk of manipulation and inoculation of human biological material.

An alternative for replacing whole cells or purified fractions of $M$. leprae is to use synthetic peptides. Previous studies have demonstrated delayed-type hypersensitivity responses to peptides in skin tests $[11,12]$. Aiming at finding alternative diagnostic supplies for leprosy, peptides binding antibody from multibacillary leprosy patients were selected from phage displayed peptide libraries and assessed in their capacity to induce cell response in guinea-pigs sensitized with M. leprae.

\section{Methods}

\section{Antigens}

The M. tuberculosis H37Rv (ATCC 27294) strain was obtained from the Instituto Adolfo Lutz, São Paulo - Brazil. The cells were grown in Middlebrook 7H10 for 14-21 days at $37^{\circ} \mathrm{C}$, followed by suspension in $0.9 \% \mathrm{NaCl}$ and inactivation at $100^{\circ} \mathrm{C}$ for 15 minutes. Irradiated $M$. leprae whole cells isolated from armadillo liver were kindly supplied by Dr. J. S. Spencer from Colorado State University (Fort Collins-USA) through the National Institute of Allergy and Infectious Diseases/National Institutes of Health under contract N01-AI-25469. Bacilli in 0.9\% $\mathrm{NaCl}$ containing $100 \mu \mathrm{g} / \mathrm{mL}$ phenylmethylsulfonyl fluoride (PMSF) and $2 \mathrm{mM}$ ethylenediaminetetraacetic acid (EDTA) were broken by sonication (Sonopuls HD 2200, Bandelin, Berlin-Germany) four cycles of 15 minutes [13]. Following lysis, the soluble fraction was separated by centrifugation at $10000 \times \mathrm{g}$ for 20 minutes at $4^{\circ} \mathrm{C}$, and the protein concentration was determined using the Quant-iT Protein Assay kit (Invitrogen, California-USA).

\section{Patient serum samples}

Serum samples of 10 paucibacillary patients (PB), 23 multibacillary patients (MB), and 26 household contacts were obtained. The samples were collected at the Hospital de Dermatologia Sanitária (Piraquara, Paraná-Brazil), Centro Regional de Especialidades-Barão (Curitiba, ParanáBrazil), Fundação Pró-Hansen (Curitiba, Paraná-Brazil), and at Sociedade Filantrópica Humanitas (São Jerônimo da Serra, Paraná-Brazil). Among the leprosy patients, 14 had not yet started the treatment by the time of blood collection, and 19 were under treatment (days - 4 months). Serum of 30 patients with pulmonary tuberculosis (TB) under treatment (days - 3 months) - was obtained at the Centro Regional de Especialidades-Barão (Curitiba, ParanáBrazil) and at the Hospital Regional da Lapa 'São Sebastião' (Lapa, Paraná-Brazil). Leprosy and TB patients were diagnosed and classified by a specialized physician at the Health Units. Serum of 30 endemic controls was obtained from volunteers with no history of infection by leprosy and tuberculosis. In all cases, drawing of blood was carried out with informed consent and approved by the Research Ethics Committee of Federal University of Paraná (Comitê de Ética em Pesquisa, Setor de Ciências da Saúde, Universidade Federal do Paraná).

\section{Immunoglobulins anti-M. leprae and anti-M. tuberculosis}

IgG of the sera pool from MB patients were obtained by precipitation with ammonium sulfate followed by chromatography using protein G-agarose [14]. The anti- $M$. leprae IgGs were recovered from immunoblots. For that, the $M$. leprae protein extract was resolved by SDSPAGE in gradient polyacrylamide gel 10-20\%; after having been transferred to the PVDF membrane, IgGs binding antigen immobilized in membrane were eluted with $0.1 \mathrm{M}$ glycine, $0.15 \mathrm{M} \mathrm{NaCl}, \mathrm{pH} 2.8$ at room temperature for 30 minutes. Anti- $M$. leprae IgGs were dialyzed against PBS after neutralization with $1 \mathrm{M}$ Tris$\mathrm{HCl}, \mathrm{pH}$ 9.0, and the protein concentration was determined by the Bradford method [15]. The same process was repeated using a sera pool from tuberculosis patients and $M$. tuberculosis protein in order to obtain anti-M. tuberculosis antibodies.

\section{Screening of random peptide phage display libraries}

Linear (X15 and X8CX8) and constrained (XCX4CX and XCX8CX) random peptide libraries were obtained from J. Scott, Simon Fraser University (Burnaby BC-Canada). Peptides are expressed on the surface of protein pVIII of phage f88.4. Two panning strategies were used. In 
strategy I, the phages of libraries not bound to anti- $M$. tuberculosis immunoglobulins immobilized in immunotube were used in the first round of panning with anti- $M$. leprae immunoglobulins. In strategy II, the phages of libraries were directly used in the first round of panning with anti-M. leprae immunoglobulins. Panning was carried out according to the previously given description [16]. Briefly, one immunotube (Nunc, Roskilde-Denmark) was coated with anti- $M$. leprae immunoglobulin in $100 \mathrm{mM}$ $\mathrm{NaHCO}_{3}, \mathrm{pH} 8.6$ at $5 \mu \mathrm{g} / 1.5 \mathrm{~mL}$ and incubated overnight at $4{ }^{\circ} \mathrm{C}$. The immunotube was washed with TBST-0.05\% (TBS Tween 20-0.05\%), filled with blocking solution (TBST-0.05\%, 3\% BSA) and incubated for 2 hours at $37^{\circ} \mathrm{C}$. For the first round of panning, $1.5 \times 10^{11}$ phages of libraries $\mathrm{X} 15$ and XCX8CX, and $2.5 \times 10^{10}$ phages of libraries X8CX8 and XCX4CX were incubated in TBST-0.05\% with the immobilized antibodies. After the washings with TBST$0.5 \%$, the bound phages were eluted with $1.5 \mathrm{~mL} 0.1 \mathrm{M}$ glycine, $\mathrm{pH} 2.2,1 \mathrm{mg} / \mathrm{mL}$ BSA. After neutralization with $2 \mathrm{M}$ Tris- $\mathrm{HCl}, \mathrm{pH}$ 9.0, the eluted phages were amplified by infecting a culture of $E$. coli $\mathrm{K} 91$. After incubation overnight at $37^{\circ} \mathrm{C}$, the supernatant was obtained and precipitated with PEG/NaCl. In the remaining rounds, $2 \times 10^{11}$ amplified phages of the previous cycle were incubated with $\mathrm{IgG}$ anti- $M$. leprae. The procedures were equal to those applied to the first round except for the fact that the concentration of the antibody immobilized to the immunotube was $1 \mu \mathrm{g}$ and $0.5 \mu \mathrm{g}$ in the second and subsequent rounds, respectively.

\section{Immunological screening of phage clones}

After four rounds of panning, individual colonies containing phages were picked at random and grown overnight at $37^{\circ} \mathrm{C}$ in a 96-well microtiter plates in LB medium containing $20 \mu \mathrm{g} / \mathrm{mL}$ tetracycline. The plates were centrifuged $(1600 \times \mathrm{g}, 20$ minutes) and supernatant containing phages was analyzed regarding its binding to IgG from leprosy patients by ELISA. Microtiter plates (Falcon, BD Biosciences, California-USA) were coated by incubating $50 \mu \mathrm{L}$ anti-phage antibody (Sigma-Aldrich, Missouri-USA) diluted $1: 800$ in $100 \mathrm{mM} \mathrm{NaHCO}_{3}$, $\mathrm{pH}$ 8.6, overnight at $4{ }^{\circ} \mathrm{C}$. The plates were washed with PBST-0.05\% and blocked with $2 \%$ skimmed milk powder in PBST- $0.05 \%$ for 1 hour at $37^{\circ} \mathrm{C}$. The supernatant of each phage clone was added to each microtiter well. As a negative control, the supernatant of the E. coli $\mathrm{K} 91$ culture was used. After incubation for 2 hours at $37^{\circ} \mathrm{C}$, the plate was washed and incubated with $100 \mu \mathrm{g} / \mathrm{mL}$ IgG for 1 hour at $37^{\circ} \mathrm{C}$. After washing, peroxidase conjugated antihuman antibody (Sigma-Aldrich, Missouri-USA) - diluted 1:10000 in a blocking solution for 1 hour at $37^{\circ} \mathrm{C}$ was added. After washing, bound antibodies were monitored for determining the peroxidase activity using o-phenylenediamine dihydrochloride (OPD) (Sigma-
Aldrich, Missouri-USA) as chromogen for measuring absorbance at $492 \mathrm{~nm}$. The most reactive clones (absorbance at least twice as high as the negative control) were selected for DNA sequencing and subsequent identification of the peptide sequence inserted into the phages.

\section{Determination of peptide sequences}

Single-stranded DNA was prepared out of phage clones using QIAprep Spin M13 kit (Qiagen, Hilden-Germany). Peptide sequences of the positive phage clones were determined by the BigDye Terminator v3.1 kit (Applied Biosystems, California-USA) using the reverse primer 5'-TCGGCAAGCTCTTTTAGG-3'.

\section{Phage-ELISA}

Reactivity of the phage clones most reactive in the presence of human serum was measured by ELISA according to description given above. Microtiter plates were coated with anti-phage antibody and incubated with $2 \times 10^{10}$ phages $/ \mathrm{mL}$ followed by the addition of sera from leprosy patients, tuberculosis patients, household contacts of leprosy patients, and endemic controls, diluted 1:100. The detection of the reaction was performed with peroxidase conjugated anti-human antibody and OPD as chromogen.

\section{Synthetic peptides}

Peptides were synthesized using solid phase 9fluorenilmetoxycarbonyl (Fmoc) chemistry by PepTron (Daejon-Korea). Peptide purity was equal to or higher than $70 \%$.

\section{Guinea pigs and delayed-type hypersensitivity responses}

The experiments with these animals followed the guidelines of Brazilian College of Animal Experimentation (Colégio Brasileiro de Experimentação Animal - COBEA) and were approved by the institutional committee of Federal University of Paraná.

Three groups of five 250-300 g outbred female guinea pigs (Cavia porcellus) were used for the skin test. The antigens were diluted in $0.9 \% \mathrm{NaCl}$. The Mitsuda lepromin $\left(4 \times 10^{7}\right.$ bacilli $\left./ \mathrm{mL}\right)$ provided by the Centro de Produção e Pesquisa de Imunobiológicos (Piraquara, Paraná-Brazil) was used as positive control, and $0.9 \%$ $\mathrm{NaCl}$ was used as negative control. Five animals (group I) were sensitized by subcutaneous inoculation of $200 \mu \mathrm{g}$ [17] of $M$. leprae in Freund's incomplete adjuvant (Sigma-Aldrich, Missouri-USA). As control, five animals (group II) received $0.9 \% \mathrm{NaCl}$ in Freund's incomplete adjuvant subcutaneously. Control group III consisted of non-sensitized animals. After 30 days, each animal received, intradermally, $0.1 \mathrm{~mL}$ of the antigens: peptides (10 and $2 \mu \mathrm{g}$ ), peptide pool (10 and $2 \mu \mathrm{g}$ ), Mitsuda lepromin (positive control), soluble extract of $M$. leprae 
(10 $\mu \mathrm{g}$, positive control) and $0.9 \% \mathrm{NaCl}$ (negative control). The diameter of the skin reaction was measured after 24 , 48, and 72 hours, 21 and 28 days.

\section{Bioinformatics}

The peptide sequences were analyzed for sequence similarity using FASTA program on $M$. leprae sequence data (http://genolist.pasteur.fr/Leproma/).

\section{Results and discussion}

In order to identify mimotopes of mycobacterial antigens, peptide libraries displayed by phage were selected by affinity using M. leprae antigen-specific antibodies. The antibodies were obtained from a pool of sera from $\mathrm{MB}$ patients. The IgGs were purified by ammonium sulfate precipitation and affinity chromatography followed by elution from membranes containing $M$. leprae antigens bound. The total IgGs from $\mathrm{MB}$ patients recognized proteins in $M$. leprae especially below $50 \mathrm{kDa}$ (Figure 1B, lane 1). The same profile of reactivity was seen with antigen-specific IgGs (Figure 1B, lane 2), however, the antibody preparation method represent an important purification and concentration step, as relatively specific

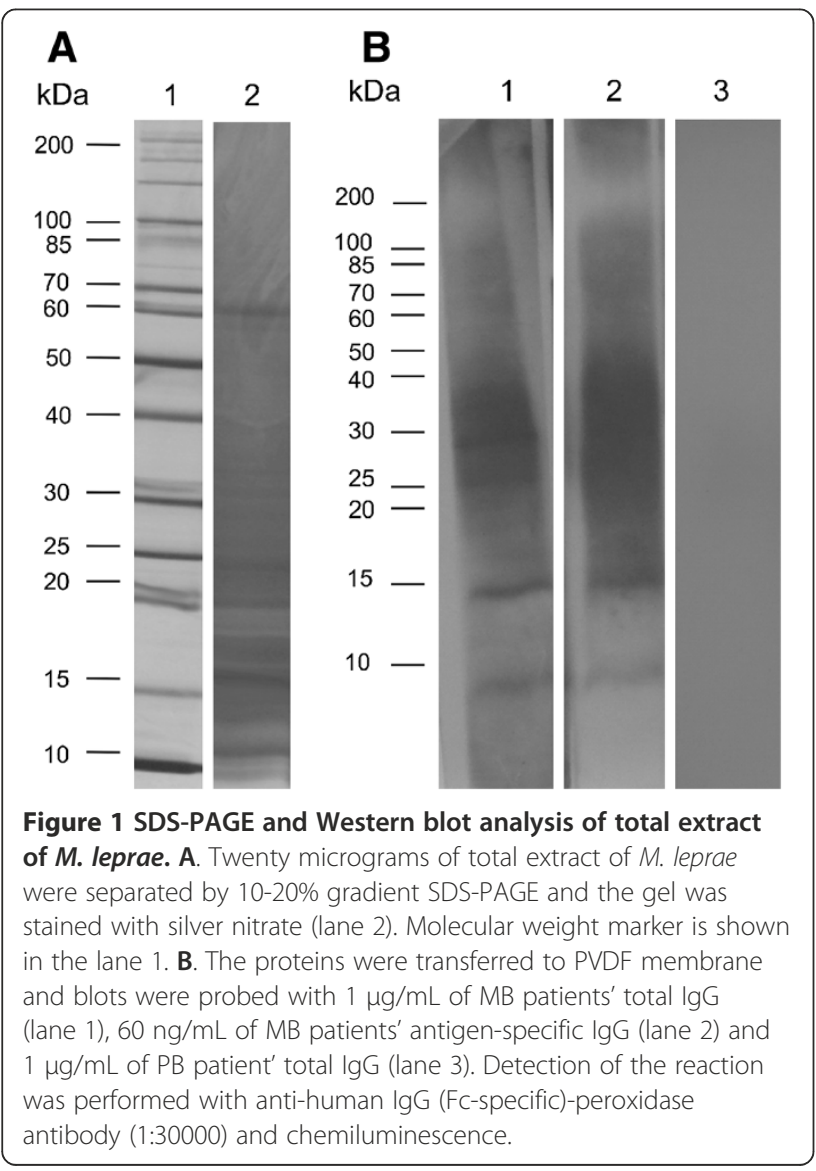

antibodies are purified from total IgG well as most of the extraneous IgGs active against other antigens are removed. Lipoarabinomannan (LAM) is a major antigen of $M$. leprae that is recognized by immunoglobulins in sera from leprosy patients [18] and runs as a broad diffuse band from 30-40 kDa as shown in Figure 1.

Two panning strategies were used. In one of them, the phage pool with anti- $M$. leprae antibodies, was depleted of reactive phages with anti- $M$. tuberculosis antibodies. Four rounds of affinity selection were performed and the amplified phage pool of each selection round was assessed by ELISA (Figure 2). In both strategies, an increase of reactivity was observed with each round of panning. However, the best result was detected between the phages and the IgG obtained in strategy II.

The phage pool of the last selection round was then chosen to isolate individual positive clones. Each phage clone was assessed - by ELISA - regarding its ability to bind to IgG of multibacillary patients. In strategy I, 24 out of 400 clones analyzed showed recognition against patients' antibodies, and 6 different peptide sequences were identified. In strategy II, 36 out of the 342 clones were recognized for binding to antibodies against leprosy and all expressed an identical sequence of 15 aminoacids.

The respective phage clones carrying the identified peptide sequences were then assessed against sera of leprosy patients and controls by ELISA (Figure 3). Reactive control samples were the same regardless of the assessed clones, which could indicate an unspecific reaction between serum and phages.

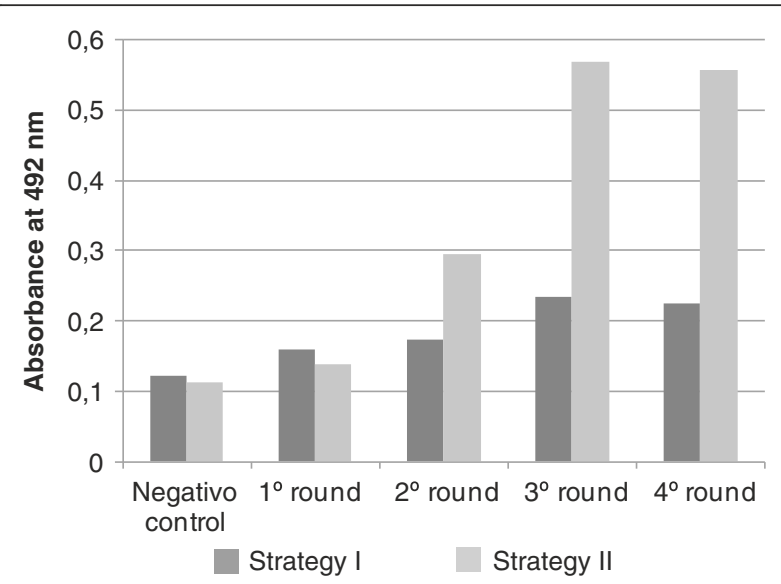

Figure 2 Reactivity of phages pools selected by affinity strategies at each selection round by ELISA. Microtiter plate was coated with anti-phage antibody (1:800) and incubated with $2 \times 10^{10}$ phages $/ \mathrm{mL}$ followed by the addition of $\operatorname{lgG}(100 \mu \mathrm{g} / \mathrm{mL})$. The detection of the reaction was performed with peroxidase conjugated anti-human antibody and OPD as chromogen. Values of absorbance at $492 \mathrm{~nm}$ are means of duplicates. Wild phage was used as negative control. 

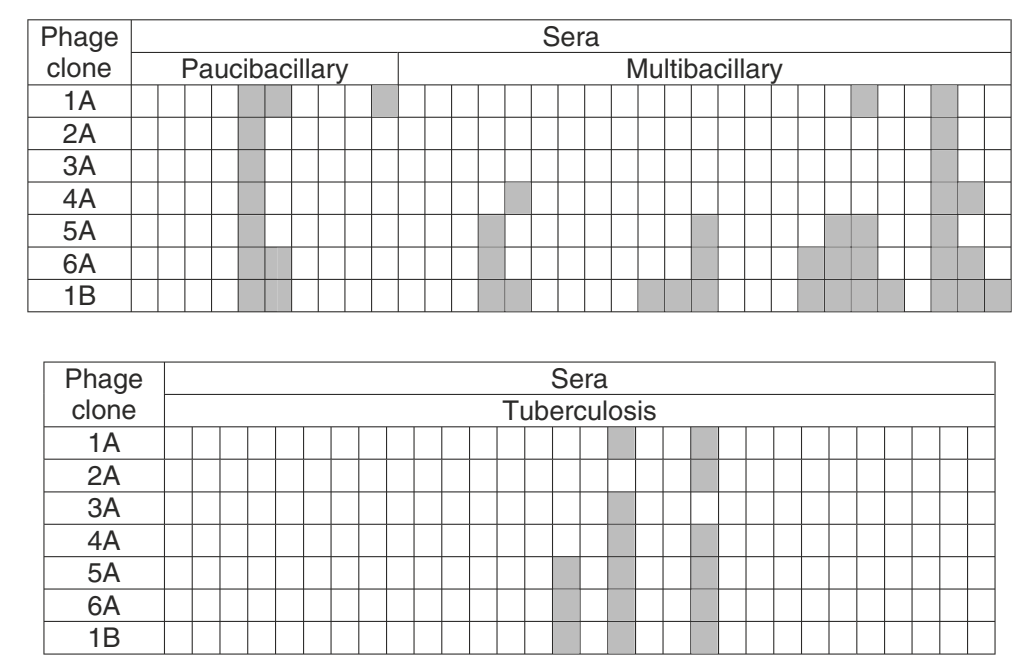

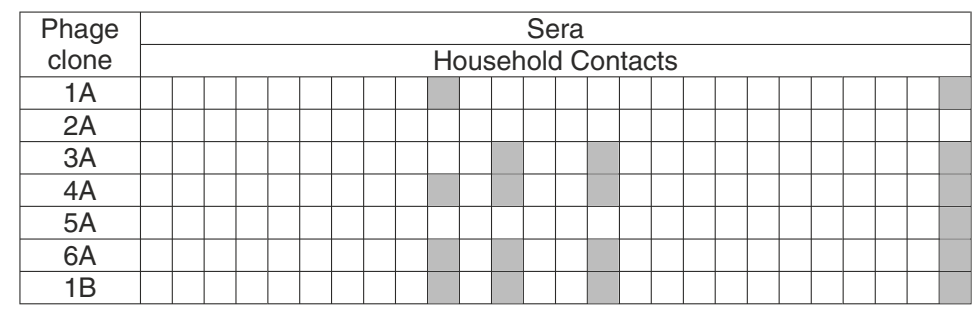

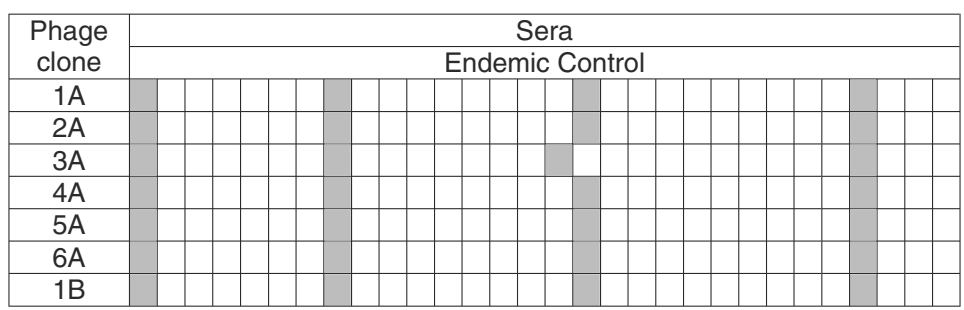

Figure 3 Reactivity of phage clones by ELISA with sera of patients and controls. Microtiter plates were coated with anti-phage antibody $(1: 800)$ and incubated with $2 \times 10^{10}$ phages $/ \mathrm{mL}$ followed by the addition of sera (1:100). The detection of the reaction was carried out with peroxidase conjugated anti-human antibody and OPD as chromogen. Each cell in the table represents an individual. The analysis was performed in duplicate and the hatched cells represent positive samples. The cut-off value was calculated as the average of the optical density plus twice the standard deviation obtained with endemic controls.

Seven phage clones were selected and, among them, clones $5 \mathrm{~A}$, and $6 \mathrm{~A}$, clones isolated by strategy $\mathrm{I}$, and $1 \mathrm{~B}$, clone isolated by strategy II, were detected in a higher number of leprosy patients when compared to the negative controls. Even for the selected clones, a low sensitivity was observed in the detection of leprosy patients. Each serum sample was also tested with wild phage by ELISA in order to evaluate the cross reaction of the serum with the phage without the insert. The results show that the reaction of the phage clones was stronger than that of the wild phage with the positive sera samples against the phage clones (data not shown), indicating that the reactivity happened exclusively between the antibodies and the peptides expressed on the surface of the phages.
The search for similarity of peptide sequences in Leproma database showed that the peptides selected mimic mainly proteins in M. leprae (Table 1$)$. However, the LAM antigen, from which mimotopes can be isolated, would not be detected by FASTA approach. Further studies could reveal if those peptides represents mimotopes of the same antigen or of different antigens. Comparison of selected mimotopes and the native antigen sequence could lead to a better understanding of molecular mechanisms that participate in the immune response and the design of peptides for diagnostic purposes [19].

Since a humoral response depends on T helper cell response, the peptides identified were assessed regarding their ability to induce a delayed-type hypersensitivity 
Table 1 Similarity search between peptide sequence and $M$. leprae sequence database

\begin{tabular}{|c|c|c|c|}
\hline \multirow[t]{2}{*}{ Peptide } & \multirow{2}{*}{$\begin{array}{c}\text { Size } \\
\text { (amino } \\
\text { acids) }\end{array}$} & \multicolumn{2}{|r|}{ Potential antigens } \\
\hline & & M. leprae Sanger ID & Description \\
\hline \multirow[t]{10}{*}{$5 \mathrm{~A}$} & 15 & ML2028 & Secreted antigen $85-\mathrm{B} \mathrm{fbpB}$ \\
\hline & & ML0781 & Conserved hypothetical protein \\
\hline & & ML1135 & Probable protoporhyrinogen oxidase hemK homolog \\
\hline & & ML0041 & Possible secreted protease \\
\hline & & ML0053C & Possible conserved transmembrane protein \\
\hline & & ML2031 & Conserved hypothetical protein \\
\hline & & ML0213 & Possible cell cycle protein Mes」 \\
\hline & & ML2307c & Probable transcriptional regulatory protein WhiB-like whiB4 \\
\hline & & ML2137 & Conserved hypothetical protein \\
\hline & & ML1177c & Probable conserved liproprotein IprD \\
\hline \multirow[t]{7}{*}{$6 \mathrm{~A}$} & 12 & ML2263C & Probable naphthoate synthase menB \\
\hline & & ML2028 & Secreted antigen 85-B fbpB \\
\hline & & ML2030 & Probable resuscitation-promoting factor rpfC \\
\hline & & ML0053C & Possible conserved transmembrane protein \\
\hline & & ML0679 & Hypothetical protein \\
\hline & & ML 0468c & Possible conserved integral membrane protein \\
\hline & & ML0213 & Possible cell cycle protein Mes」 \\
\hline \multirow[t]{12}{*}{$1 \mathrm{~B}$} & 15 & ML2028 & Secreted antigen $85-\mathrm{B}$ fbpB \\
\hline & & ML0097 & Secreted antigen 85-A FbpA \\
\hline & & ML2485C & Possible RNA methyltransferase \\
\hline & & ML1195 & Isoleucyl-tRNA synthetase lleS \\
\hline & & ML2324 & 2-isopropylmalate synthase leuA \\
\hline & & ML2409C & Possible cytochrome C-type biogenesis protein ccsA \\
\hline & & ML2597 & Probable conserved Mce associated protein \\
\hline & & ML0455c & Conserved hypothetical protein \\
\hline & & ML1037c & Conserved hypothetical protein \\
\hline & & ML0052C & Conserved hypothetical protein \\
\hline & & ML0130c & Probable methyltransferase \\
\hline & & ML0369c & Conserved hypothetical protein \\
\hline
\end{tabular}

Potential antigens corresponds to the best scores obtained for each peptide sequence as a query sequence against $M$. leprae database using FASTA search.

response in guinea-pigs sensitized with $M$. leprae. The use of guinea-pigs constitutes the animal model used in delayed-type hypersensitivity tests with $M$. leprae antigens, according to description presented previously [17,20-22]. The intradermal challenge with peptides in animals previously sensitized with $M$. leprae induced delayed-type hypersensitivity. The maximum reading was observed in 48 hours and, therefore, that time was considered in the description of the results. No reactions were detected in animals sensitized with adjuvant as well as in non-sensitized animals. In the group sensitized with $M$. leprae, a DTH reaction was observed with peptide 5A (2/5), peptide $1 \mathrm{~B}(1 / 5)$, Mitsuda lepromin (3/5), and with $M$. leprae (4/5) (Figure 4). For peptide $1 \mathrm{~B}$, the skin reaction was observed for both 2 and $10 \mu \mathrm{g}$ doses with similar sizes - $16.5 \mathrm{~mm}$ and $15.5 \mathrm{~mm}$ respectively whereas for peptide $5 \mathrm{~A}$, only the $10 \mu \mathrm{g}$ dose generated a response. The two animals that did not respond to Mitsuda lepromin in 48 hours produced a response after 72 hours (induration) or 21 days (induration) after the application of the antigen. The detection of response with Mitsuda lepromin and the soluble extract of $M$. leprae indicate that the animals were sensitized. The skin reactions observed were erythematous; only one of the animals immunized with $M$. leprae, besides the erythema, also developed a papule as a result of applying peptide $5 \mathrm{~A}$.

The lack of cellular response in other animals is probably due to the influence of genetic factors involving genes $\mathrm{MHC}$ in the responses to peptides [11,23]. Thus, 


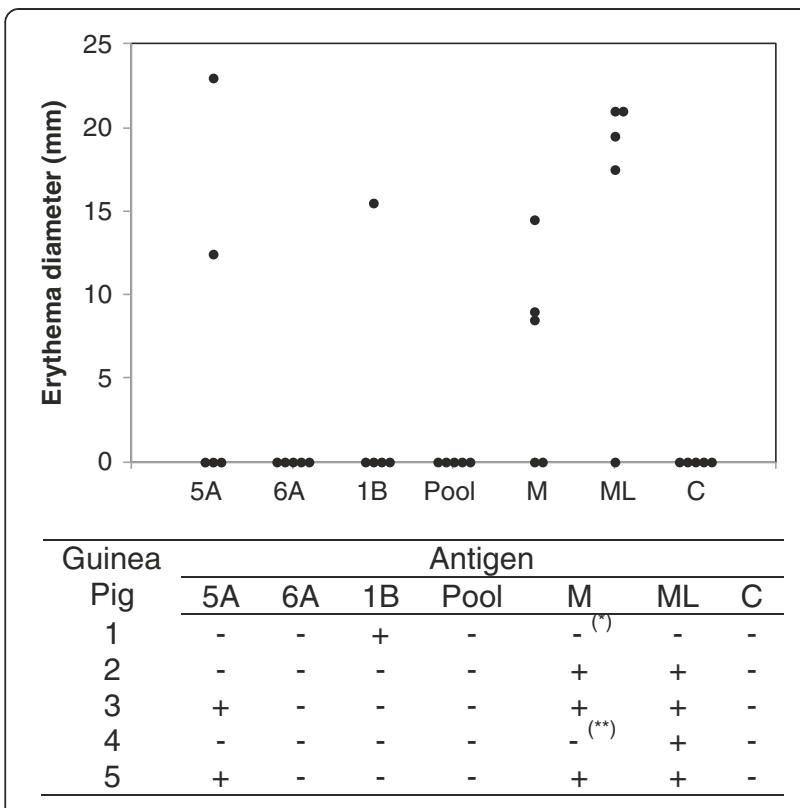

Figure 4 Delayed-type hypersensitivity response induced by peptides in guinea-pigs. Guinea-pigs were sensitized with $200 \mu \mathrm{g}$ M. leprae in Freund's incomplete adjuvant and - after 30 days - were inoculated intradermally with peptides and controls. Each group contained five animals. The result in 48 hours after application of $10 \mu \mathrm{g}$ peptides, Mistsuda lepromin (M) with $4 \times 10^{6}$ bacilli and $10 \mu \mathrm{g}$ soluble extract of $M$. leprae (ML) is indicated. The peptide pool contain equimolar amounts of the three peptides. The diameter of the reaction corresponds to the average of horizontal and vertical diameters of the erythema. $0.9 \% \mathrm{NaCl}(\mathrm{C})$ was used as negative control. * The animal responded after 72 hours. ${ }^{*}$ The animal responded after 21 days.

the mixture of peptides able to recognize different forms of disease or different genetic aspects could help to overcome problems of genetic restriction to individual peptides. Other factors that need to be evaluated are the dosage and the constitution of the antigen as, for example, the conjugation with proteins or modification of the peptide structure. Differences were found in the DTH response regarding the dosage of the inoculated peptide $[11,24]$. Other studies have tested peptides in the form of peptide-protein conjugation proteins [25] or as peptides modified by the addition of fatty acids and acetylation [26].

Differences in reactivity between phage clones and the corresponding free peptide have been described previously $[27,28]$. When in phage, the sequence could to assume a favorable position to act as binder of antibodies [29] and therefore this conformation could disappear when used as synthetic peptides. Likewise, the conformation of the peptide expressed on the phage surface may discourage recognition by antibodies. Thus, other peptide sequences identified but not included in DTH tests will be evaluated in future studies. The decision was to limit the tests to the phage clones that were reactive with larger number of patients. The selection of mimotopes was based on seroreactivity and therefore these mimetic peptides correspond to B cell epitopes. The strategy of the study was to test whether these peptides would be able to act as T cell epitopes. Serological and cellular assays, as proposed initiated this study may determine whether a peptide can comprise a serological or $\mathrm{T}$ cell test reagent. Tests for humoral immune response benefit lepromatous patients while tests for evaluation of cellular response will aid in the diagnosis of tuberculoid patients.

Lepromin is probably the only skin test antigen that reflects the individual's ability to generate a granulomatous response to mycobacterial antigens, as opposed to the 48-72 hours delayed-type hypersensitivity response found with tuberculin and other skin tests [7]. In the lepromin test, the Fernandez reaction is similar to the reaction produced by tuberculin, since it assesses the delayed-type hypersentivity of the individual to $M$. leprae soluble antigens [22]. In this aspect, the present study proposes the use of peptides in skin tests to assess the cellular response, similar to the one captured by the Mantoux test used in tuberculosis. Besides in vivo studies, the peptides identified can be assessed in the future regarding their ability to induce INF- $\gamma$ production by peripheral blood mononuclear cells of patients, aiming to verify whether those reagents allow the detection of the paucibacillary disease. However, the skin tests are more feasible and useful as compared to INF- $\gamma$ production assays, since the latter is dependent on the access to advanced lab facilities and trained personnel, which limits its use in countries with limited resources [30], a proposal advocated in the present study. Recently, the development of a user-friendly assay to detect multiple cytokines [31] which can make INF- $\gamma$ detection assays more accessible and easier to perform was reported.

Synthetic peptides prove to be very attractive to be used in diagnostic tests or for monitoring the degree of exposure to leprosy within different communities, or even an adjunct to leprosy control programs [32], since they are easy to produce with reproducibility, as well as high quality and purity control [33]. In addition, synthetic peptides can be easily obtained at a low production cost through chemical synthesis. Comparatively, crude antigens originating from $M$. leprae are complex mixtures that carry proteins of humans or animal tissues in their composition, which may pose biological risks.

\section{Conclusions}

Peptides mimotopes were isolated from phage displayed libraries by screening purified antibodies derived from leprosy patients' sera. Our strategy was to evaluate the ability of mimotopes to induce cellular response in DTH tests. The selected sets of peptides are also a starting 
point to the future design of more effective reagents for diagnostic purposes.

\section{Competing interests}

The authors declare that they have no competing interests.

\section{Authors' contributions}

SMA participated in designing the study, carrying out the experiments, analyzing data and writing the manuscript. JFM conceived the study, participated in designing the study and writing the manuscript. JCM participated in the execution of experiment. MTM participated in analyzing the data and writing the manuscript. VTS conceived the study, participated in designing the study, data analysis and writing of the manuscript. All the authors read and approved this final manuscript.

\section{Acknowledgments}

We would like to thank the representatives and members of the Hospital de Dermatologia Sanitária do Paraná, the Centro Regional de Especialidades-Barão, the Sociedade Filantrópica Humanitas, the Hospital Regional da Lapa São Sebastião, and the Fundação Pró-Hansen for giving us access to their facilities in order to collect samples from patients. We also thank the Centro de Produção e Pesquisa de Imunobiológicos for their cooperation; Dr. John Spencer, University of Colorado, for providing the M. leprae cells; Dr Jamie K. Scott, Simon Fraser University, for having provided the peptides libraries displayed in phages. The present research was supported by the Conselho Nacional de Desenvolvimento Científico e Tecnológico (CNPq). S.M.A. was supported by funds granted by CAPES (Coordenação de Aperfeiçoamento de Pessoal de Nivel Superior-Ministry of Education - Brazil). The authors would like to thank Dr Carlos Chávez Olórtegui for providing the wild phage.

\section{Author details}

${ }^{1}$ Engenharia de Bioprocessos e Biotecnologia, Universidade Federal do Paraná, Curitiba 81531-990, Brasil. Departamento de Patologia Básica, Universidade Federal do Paraná, Curitiba 81531-990, Brazil. ${ }^{3}$ Centro de Produção e Pesquisa de Imunobiológicos, Secretária de Saúde do Estado do Paraná, Piraquara 83302-160, Brazil. ${ }^{4}$ Centro de Ciências Biológicas e da Saúde, Pontifícia Universidade Católica do Paraná, Curitiba 80215-901, Brazil.

Received: 8 February 2012 Accepted: 22 January 2013

Published: 25 January 2013

\section{References}

1. Britton WJ, Lockwood DNJ: Leprosy. Lancet 2004, 363:1209-1219.

2. Stefani MM: Challenges in the post genomic era for the development of tests for leprosy diagnosis. Rev Soc Bras Med Trop 2008, 43(Suppl 2):89-94.

3. Bührer-Sékula S: Sorologia PGL-I na hanseníase. Rev Soc Bras Med Trop 2008, 41(Suppl 2):3-5.

4. WHO: Global leprosy situation, 2010. http://www.who.int/wer/2010/wer8535.pdf.

5. Geluk A, van der Ploeg J, Teles RO, Franken KL, Prins C, Drijfhout JW, Sarno EN, Sampaio EP, Ottenhoff TH: Rational combination of peptides derived from different Mycobacterium leprae proteins improves sensitivity for immunodiagnosis of M. leprae infection. Clin Vaccine Immunol 2008, 15:522-533.

6. Modlin RL: The innate immune response in leprosy. Curr Opin Immunol 2010, 22:48-54.

7. Scollard DM, Adams LB, Gillis TP, Krahenbuhl JL, Truman RW, Williams DL: The continuing challenges of leprosy. Clin Microbiol Rev 2006, 19:338-381.

8. WHO: Recommended safety requirements for the preparation of lepromin: a WHO Memorandum. Bull World Health Organ 1979, 57:921-923.

9. Hastings RC, Gillis TP, Krahenbuhl JL, Franzblau SG: Leprosy. Clin Microbiol Rev 1988, 1:330-348.

10. Alban SM, Sella SRBR, Miranda RN, Mira MT, Thomaz-Soccol V: PCRRestriction Fragment Length Polymorphism analysis as a tool for Mycobacterium species identification in lepromas for lepromin production. Lepr Rev 2009, 80:129-142.

11. Estrada IC, Gutiérrez MC, Esparza J, Quesada-Pascual F, Estrada-Parra S, Possani LD: Use of synthetic peptides corresponding to sequences of Mycobacterium leprae proteins to study delayed-type hypersensitivity response in sensitized guinea pigs. Int I Lepr Other Mycobact Dis 1992, 60:18-27.
12. Aaggard C, Brock I, Olsen A, Ottenhoff TH, Weldingh $K$, Andersen P: Mapping immune reactivity toward Rv2653 and Rv2654: two novel lowmolecular-mass antigens found specifically in the Mycobacterium tuberculosis complex. J Infect Dis 2004, 189:812-819.

13. Pessolani MC, Brennan PJ: Mycobacterium leprae produces extracellular homologs of the antigen 85 complex. Infect Immun 1992, 60:4452-4459.

14. Harlow E, Lane D: Antibodies: A Laboratory Manual. New York: Cold Spring Harbor Laboratory; 1988.

15. Bradford MM: A rapid and sensitive method for the quantitation of microgram quantities of protein utilizing the principle of protein-dye binding. Anal Biochem 1976, 72:248-254.

16. Villard S, Lacroix-Desmazes S, Kieber-Emmons T, Piquer D, Grailly S, Benhida A, Kaveri SV, Saint-Remy JM, Granier C: Peptide decoys selected by phage display block in vitro and in vivo activity of a human anti-FVIII inhibitor. Blood 2003, 102:949-952.

17. Melancon-Kaplan J, Hunter SW, McNeil M, Stewart C, Modlin RL, Rea TH, Convit J, Salgame P, Mehra V, Bloom BR, Brennan PJ: Immunological significance of Mycobacterium leprae cell walls. Proc Natl Acad Sci USA 1998, 85:1917-1921.

18. Gaylord H, Brennan PJ: Leprosy and the leprosy bacillus: recent developments in characterization of antigens and immunology of the disease. Ann Rev Microbiol 1987, 41:645-675.

19. Li Y, Ning $Y$, Wang $Y$, Peng $D$, Jiang $Y$, Zhang L, Long $M$, Luo J, Li M: Mimotopes selected with a neutralizing antibody against urease $B$ from Helicobacter pylori induce enzyme inhibitory antibodies in mice upon vaccination. BMC Biotechnol 2010, 10(30):84.

20. Mehra V, Bloom BR: Induction of cell-mediated immunity to Mycobacterium leprae in guinea pigs. Infect Immun 1979, 23:787-794.

21. Mehra V, Bloom BR, Bajardi AC, Grisso CL, Sieling PA, Alland D, Convit J, Fan XD, Hunter SW, Brennan PJ, Rea TH, Modlin RL: A major T cell antigen of Mycobacterium leprae is a 10-KD heat-shock cognate protein. J Exp Med 1992, 175:275-284.

22. Brennan PJ: Skin test development in leprosy: progress with firstgeneration skin test antigens, and an approach to the second generation. Lepr Rev 2000, 71 (Suppl):S50-S54.

23. Mackall JC, Bai GH, Rouse DA, Armoa GR, Chuidian F, Nair J, Morris SL: A comparison of the T cell delayed-type hypersensitivity epitopes of the 19-kD antigens from Mycobacterium tuberculosis and Myco. intracellulare using overlapping synthetic peptides. Clin Exp Immunol 1993, 93:172-177.

24. Sitz KV, Loomis-Price LD, Ratto-Kim S, Kenner JR, Sau P, Eckels KH, Redfield RR, Birx DL: Delayed-type hypersensitivity skin testing using third variable loop peptides identifies T lymphocyte epitopes in human immunodeficiency virus-infected persons. J Infect Dis 1997, 176:1085-1089.

25. Kel JM, de Geus ED, van Stipdonk MJ, Drijfhout JW, Koning F, Nagelkerken L: Immunization with mannosylated peptide induces poor T cell effector functions despite enhanced antigen presentation. Int Immunol 2008, 20:117-127.

26. Oettinger T, Holm A, Haslov K: Characterization of the delayed type hypersensitivity-inducing epitope of MPT64 from Mycobacterium tuberculosis. Scand I Immunol 1997, 45:499-503.

27. Minenkova O, Gargano N, De Tomassi A, Bellintani F, Pucci A, Fortugno P, Fuscaldi E, Pessi A, Rapicetta M, Miceli M, lundicone P, Cortese R, Felici F, Monaci P: ADAM-HCV, a new-concept diagnostic assay for antibodies to hepatitis C virus in serum. Eur J Biochem 2001, 268:4758-4768.

28. Van Nieuwenhove L, Büscher P, Balharbi F, Humbert M, Dieltjens T, Guisez $Y$, Lejon V: Identification of mimotopes with diagnostic potential for Trypanosoma brucei gambiense variant surface glycoproteins using human antibody fractions. PLoS Negl Trop Dis 2012, 6:e1682.

29. Kishchenko G, Batliwala H, Makowski L: Structure of a foreign peptide displayed on the surface of bacteriophage M13. J Mol Biol 1994, 241:208-213.

30. Lillebaek T, Bergstedt W, Tingskov PN, Thierry-Carstensen B, Aggerbeck H, Hoff ST, Weldingh K, Andersen P, Soborg B, Thomsen VO, Andersen AB: Risk of sensitization in healthy adults following repeated administration of rdESAT- 6 skin test reagent by the Mantoux injection technique. Tuberculosis 2009, 89:158-162.

31. Corstjens PL, de Dood CJ, van der Ploeg-van Schip JJ, Wiesmeijer KC Riuttamäki T, van Meijgaarden KE, Spencer JS, Tanke HJ, Ottenhoff TH, Geluk A: Lateral flow assay for simultaneous detection of cellular-and humoral immune responses. Clin Biochem 2011, 44:1241-1246. 
32. Dockrell HM, Brahmbhatt S, Robertson BD, Britton S, Fruth U, Gebre N, Hunegnaw M, Hussain R, Manandhar R, Murillo L, Pessolani MC, Roche P, Salgado JL, Sampaio E, Shahid F, Thole JE, Young DB: A postgenomic approach to identification of Mycobacterium leprae-specific peptides as T-cell reagents. Infect Immun 2000, 68:5846-5855.

33. Aráoz R, Honoré N, Banu S, Demangel C, Cissoko Y, Arama C, Uddin MK, Hadi SK, Monot M, Cho SN, Ji B, Brennan PJ, Sow S, Cole ST: Towards an immunodiagnostic test for leprosy. Microbes Infect 2006, 8:2270-2276.

doi:10.1186/1471-2334-13-42

Cite this article as: Alban et al:: Identification of mimotopes of

Mycobacterium leprae as potential diagnostic reagents. BMC Infectious

Diseases 2013 13:42.

\section{Submit your next manuscript to BioMed Central and take full advantage of:}

- Convenient online submission

- Thorough peer review

- No space constraints or color figure charges

- Immediate publication on acceptance

- Inclusion in PubMed, CAS, Scopus and Google Scholar

- Research which is freely available for redistribution 